\title{
Effects of different paper mulches on soil temperature and yield of cucumber (Cucumis sativus L.) in the temperate zone
}

\author{
Tapani Haapala, Pauliina Palonen, Antti Tamminen and Jukka Ahokas
}

Department of Agricultural Sciences, P.O. Box 62, FIN-00014 University of Helsinki, Finland

e-mail: tapani.haapala@helsinki.fi

\begin{abstract}
The effect of different paper mulches and two different biodegradable plastic mulches on the yield of field-grown cucumber (Cucumis sativus L.) was examined. The studies were conducted during two climatically different growing seasons 2011 and 2012 in Southern Finland. All the mulches increased the yield as compared to bare ground. In 2011, cucumbers on all the mulches with a dark upper surface produced higher yields than those on kraft paper alone. In 2012, when the average temperatures were lower than in 2011, there were no differences in yield between different types of mulches. Soil temperatures of the experimental plots were monitored throughout the growing seasons. The mulches with a dark-colored upper surface increased the soil temperature more than the ones with a light-colored upper surface. The soil warming effect of the mulches was greater during early season and diminished when the plants grew larger and their leaves covered most of the mulch surface. There was no need for weed control except in uncovered plots. In conclusion, during both years dark-colored paper mulch was comparable to biodegradable film in yield production and could replace it as a mulch material in cucumber production.
\end{abstract}

Key words: biodegradable plastic mulch, kraft paper, weeds, yield, soil temperature

\section{Introduction}

Low temperatures and particularly low soil temperatures limit early cucumber production in Finland and in other countries in the temperate zone with similar climate conditions. The minimum root-zone temperature for cucumber growth is $10-12{ }^{\circ} \mathrm{C}$ (Salokangas 1973). In Finland, especially in spring, the soil temperature is too low for cucumbers (Salokangas 1973) and other species with a high temperature requirement. Different mulches may improve the soil temperature, as they absorb solar radiation and thereby heat the soil (Anderson et al. 1995). The quality, transparency and color of mulch film have a significant impact on the soil temperature, and thereby on crop growth. When different mulches were tested, the soil temperature was highest under clear polyethylene, intermediate under black polyethylene and lowest when the ground was not mulched (Salokangas 1973, Nimah 2007). Paper mulches also increased the soil temperature, but not as much as clear PE sheet (Salokangas 1973). In a study by El-Nemr (2006) conducted in Cairo, Egypt, a kraft paper saturated with paraffin wax in order to increase its transparency gave the highest soil temperature and moisture compared to transparent, silver or black polyethylene mulches. The best growth and highest cucumber yield were obtained by using black polyethylene or kraft paper saturated with paraffin as mulch. Ibarra-Jiménez et al. (2008), who tested eight different colored plastic mulches in cucumber production in Mexico, suggested that the optimal color of plastic mulch needs to be determined in each specific region, as the color affects the upper soil temperature profile and the soil heat accumulation.

Weed control is an important aspect to be considered when planning vegetable production. Whether done manually, mechanically, or chemically, it accounts for a major part of the pre-harvest cost (Jenni et al. 2004). Mulches may provide weed control (Anzalone et al. 2010, Coolong 2010). Furthermore, mulching can significantly reduce the demand for irrigation and improve water use efficiency in cucumber production (Kirnak and Demirtas 2006), and may also help to control harmful insects or pests (Necibi et al. 1992).

Polyethylene is widely used as a mulch in agriculture and horticulture (Espi et al. 2006), and black-colored film has been the most popular in production (Moreno and Moreno 2008). However, there have been efforts to find alternative products for polyethylene (PE) because of the disposal problems. Minuto et al. (2008) found that starch-based biodegradable film can substitute conventional PE films for short-duration crops. They believed the cost of the biodegradable film to be comparable with that of PE film when removal and disposal costs are considered. If removal expenses are not considered, the cost of materials for growers using biodegradable mulches is 2 to 3 times higher than that of PE mulch films (Halley 2001, Sarnacke and Wildes 2008). 
In processing tomato production, the economic benefit of different biodegradable plastic mulch treatments was 52 to $76 \%$ of that for polyethylene mulch (Cirujeda et al. 2012). For paper mulch treatments, the benefit was 64 to $65 \%$ compared to polyethylene. Both paper and biodegradable films are made of renewable materials, but the raw materials for biodegradable films could also be used as food for humans or feed for animals, thus making paper mulch a more sustainable option. This option is even more sustainable if and when material for paper production is taken from certified forests and/or the paper material is recycled.

The aim of our study carried out in southern Finland was to examine the effects of different paper mulches on the yield of cucumber, the soil temperature, and weed emergence, and to assess whether paper mulches could substitute biodegradable film mulch in cucumber production. Because paper materials and biodegradable film have not proven to be durable enough alone (Hochmuth and Hochmuth 1994, Moreno and Moreno 2008), we also tested papers coated with biodegradable films.

\section{Materials and Methods}

The study was conducted in the experimental field of the Faculty of Agriculture and Forestry of the University of Helsinki (latitude, $60^{\circ} 13^{\prime} \mathrm{N}$; longitude, $25^{\circ} 01^{\prime} \mathrm{E}$ ) in 2011 and 2012. Average monthly temperatures and rainfall during these years are presented in Table 1. Growing season of 2011 was warmer than the average during the years 1981-2010.

\section{Plant material}

Cucumber (Cucumis sativus L., cv. Dirigent) seeds were sown in a greenhouse on 27 May in 2011, and on 22 May in 2012. The seedlings were grown for 24 days according to commercial practice before transplanting for the field trial.

\section{Mulches}

In both years, four paper mulches, a biodegradable film and bare ground (BG) as a control were used. In 2011, the paper mulches were: brown kraft paper $70 \mathrm{~g} \mathrm{~m}^{-2}(\mathrm{~K})$, brown kraft paper $70 \mathrm{~g} \mathrm{~m}^{-2}$ with the underside coated with black biodegradable film (K1), brown kraft paper $70 \mathrm{~g} \mathrm{~m}^{-2}$ with both sides coated with black biodegradable film (K2), and brown kraft paper $70 \mathrm{~g} \mathrm{~m}^{-2}$ with the upper side colored black by using carbon black (KB). The biodegradable film (BDF) was black and made of maize starch (thickness $30 \mu \mathrm{m}$, commonly used in Finland). K, K1, K2, and KB were under development by different paper manufacturers, and BDF was a commercial product. In 2012, the paper mulches were: brown kraft paper $70 \mathrm{~g} \mathrm{~m}^{-2}$ with the upper side colored black (KB), MimGreen kraft paper 85 $\mathrm{g} \mathrm{m}^{-2}$ with black upper side (MIMGROUP, Spain) (MG), creped brown kraft paper $60 \mathrm{~g} \mathrm{~m}^{-2}$ (CK), and creped brown kraft paper $60 \mathrm{~g} \mathrm{~m}^{-2}$ with wax coating (CKW). The biodegradable film (BIO) was made of maize starch (thickness $18 \mu \mathrm{m}$ ) (Bioska, Plastiroll, Finland). KB, CK, and CKW were under development, whereas MG and BIO were commercial products.

\section{Field trial}

The clay loam soil of the trial area was prepared by ploughing and harrowing. The trial area was fertilized with $130 \mathrm{~kg} \mathrm{~N} \mathrm{ha}^{-1}, 43 \mathrm{~kg} \mathrm{P} \mathrm{ha}^{-1}$ and $173 \mathrm{~kg} \mathrm{~K} \mathrm{ha}^{-1}$ in 2011. In 2012 the trial area was fertilized with $116 \mathrm{~kg} \mathrm{~N} \mathrm{ha}^{-1}, 39 \mathrm{~kg}$ $\mathrm{P} \mathrm{ha}^{-1}$ and $155 \mathrm{~kg} \mathrm{~K} \mathrm{ha}^{-1}$, and $11 \mathrm{~kg} \mathrm{~N} \mathrm{ha}^{-1}, 6 \mathrm{~kg} \mathrm{P} \mathrm{ha}^{-1}$ and $17 \mathrm{~kg} \mathrm{~K} \mathrm{ha}^{-1}$ were added through drip irrigation two times during the growing season. Four 0.7-m-wide and 0.10-m-high beds that served as blocks in the experimental design were formed with a laying machine (Avagro, Finland). Experimental plots ( $0.7 \times 1.5 \mathrm{~m}$ in size) were arranged in a randomized complete block design within four blocks (=beds). Paper mulches were laid on the beds manually and their edges were buried in soil just before planting the cucumber seedlings. Mulches were applied manually due to the complicated lay-out of the experiment which did not allow mechanical application. Transplantation was carried out manually on 20 June in 2011, and on 15 June in 2012 in two interlaced rows with a distance of $30 \mathrm{~cm}$ between the plants. There were five plants in each plot and one buffer plant between the plots.

Throughout the growing season of 2011, the average temperatures were higher than in 2012 (Table 1). Furthermore, rainfall in August 2011 was much greater than in August 2012. The plots were watered when needed with an overhead sprinkler in 2011 and through drip irrigation in 2012. All the treatments received equal amount of irrigation water. In 2011, weeding of the uncovered control plots was carried out once during the growing season. In 2012, the plots were weeded 45 days after transplanting and the total dry weight of all the weeds harvested from the whole plot was measured. 
Cucumbers were harvested twice a week starting on 19 July and on 20 July, and finishing on 23 September and on 19 September, in 2011 and 2012, respectively. The cucumbers were weighed immediately after harvesting with a precision scale and their diameter was measured to determine if it was within the industrial standard $(25-45 \mathrm{~mm})$. The commercial yield as $\mathrm{kg} \mathrm{m}^{-2}$ was calculated so that $10 \%$ of cucumbers could exceed the $45-\mathrm{mm}$ size limit, as is determined in the standard.

\section{Temperature and moisture monitoring}

The soil conditions of all plots were monitored at 10-cm depth with temperature and moisture sensors (Decagon 5TM, USA) connected to data loggers (Decagon Em50) once in every 30 minutes (moisture measurement data not included in this article).

\section{Statistics}

The data were subjected to analysis of variance in PASW Statistics 18 (IBM SPSS Inc.). Treatment means were separated using Student-Newman-Keuls (S-N-K) test at $p<0.05$.

Table 1. Average monthly temperature and rainfall during the experimental years 2011 and 2012, and the average during 1981-2010

\begin{tabular}{lcccccc}
\hline & \multicolumn{5}{c}{ Temperature $\left({ }^{\circ} \mathrm{C}\right)$} & \multicolumn{5}{c}{ Rainfall $(\mathrm{mm})$} \\
\cline { 2 - 7 } & 2011 & 2012 & $1981-2010$ & 2011 & 2012 & $1981-2010$ \\
June & 16.7 & 13.7 & 14.6 & 49 & 88 & 57 \\
July & 20.6 & 17.8 & 17.7 & 56 & 54 & 63 \\
August & 17.5 & 16.0 & 16.3 & 173 & 39 & 80 \\
September & 13.6 & 12.5 & 11.5 & 88 & 160 & 56 \\
\hline
\end{tabular}

\section{Results and Discussion}

In 2011, the average soil temperature under the double-coated black kraft paper (K2) was on average $1^{\circ} \mathrm{C}$ higher than under kraft paper (K), kraft paper coated on the underside with black biodegradable film (K1), or that of bare ground (BG) (Table 2). In June and July, soil temperatures were highest under K2 and lowest under K1, other mulches being intermediate between these two (Fig. 1). In June, soil under the black-surfaced mulches (K2, BDF and KB) was warmer than under K1 or bare ground. In general, those of our mulches that had a dark color on the upper surface increased the temperature of soil more than the ones with a light-colored upper surface. Dark colors reflect and transmit less shortwave radiation than light colors and also absorb more shortwave radiation. This increases the soil temperature in the upper soil profile (Ibarra-Jiménez et al. 2008). The differences between the mulches diminished during the season, as the cucumber leaves covered all of the mulch, and mulch color no longer played any role. In July, soil temperature under K2 was still higher than that of bare ground and under paper with a brown surface (K and K1). In August, only K2 significantly increased soil temperature as compared to bare ground.

Cucumbers on all of the mulches with dark upper surfaces (KB, BDF, K2) produced higher yields than kraft paper alone (Table 2). All the mulches produced significantly higher yields than when the soil was left bare. All paper mulches, except untreated kraft paper, were equally good as compared with biodegradable mulch film. 
T. Haapala et al. (2015) 24: 52-58

Table 2. Number of fruits and yield of cucumbers grown on different mulches, and average soil temperatures (T) under the mulches in 2011. BG = bare ground, $\mathrm{KB}=$ brown kraft paper with the upper surface colored black, BDF = biodegradable film, $\mathrm{K}=$ brown kraft paper, $\mathrm{K} 1$ = brown kraft paper coated on the underside with black biodegradable film, K2 = brown kraft paper coated on both sides with black biodegradable film.

\begin{tabular}{lccc}
\hline Mulch & $\begin{array}{c}\text { Fruits } \\
\left(\mathrm{no} \mathrm{m}^{-2}\right)\end{array}$ & $\begin{array}{c}\text { Yield } \\
\left(\mathrm{kg} \mathrm{m}^{-2}\right)\end{array}$ & $\begin{array}{c}\text { T June to Sept. } \\
\left({ }^{\circ} \mathrm{C}\right)\end{array}$ \\
\hline BG & $104^{\mathrm{y}} \pm 1 \mathrm{c}$ & $9.5^{\mathrm{y}} \pm 0.2 \mathrm{c}$ & $18.0 \mathrm{~b}$ \\
$\mathrm{~KB}$ & $148 \pm 4 \mathrm{a}$ & $14.3 \pm 0.7 \mathrm{a}$ & $18.3 \mathrm{ab}$ \\
$\mathrm{BDF}$ & $153 \pm 4 \mathrm{a}$ & $14.2 \pm 0.5 \mathrm{a}$ & $18.7 \mathrm{ab}$ \\
$\mathrm{K}$ & $125 \pm 8 \mathrm{~b}$ & $11.7 \pm 0.6 \mathrm{~b}$ & $18.1^{\mathrm{y}} \mathrm{b}$ \\
$\mathrm{K} 1$ & $141 \pm 5 \mathrm{ab}$ & $13.2 \pm 0.3 \mathrm{ab}$ & $18.0^{\mathrm{y}} \mathrm{b}$ \\
$\mathrm{K} 2$ & $155 \pm 6 \mathrm{a}$ & $15.2 \pm 0.6 \mathrm{a}$ & $19.1^{\mathrm{y} a}$ \\
$p$ & $<0.001$ & $<0.001$ & 0.023 \\
\hline
\end{tabular}

Values are means of four replicates and followed by \pm SEM. Values within columns followed by different letters are significantly different $(p<0.05)$ according to SNK test.

y $n=3$
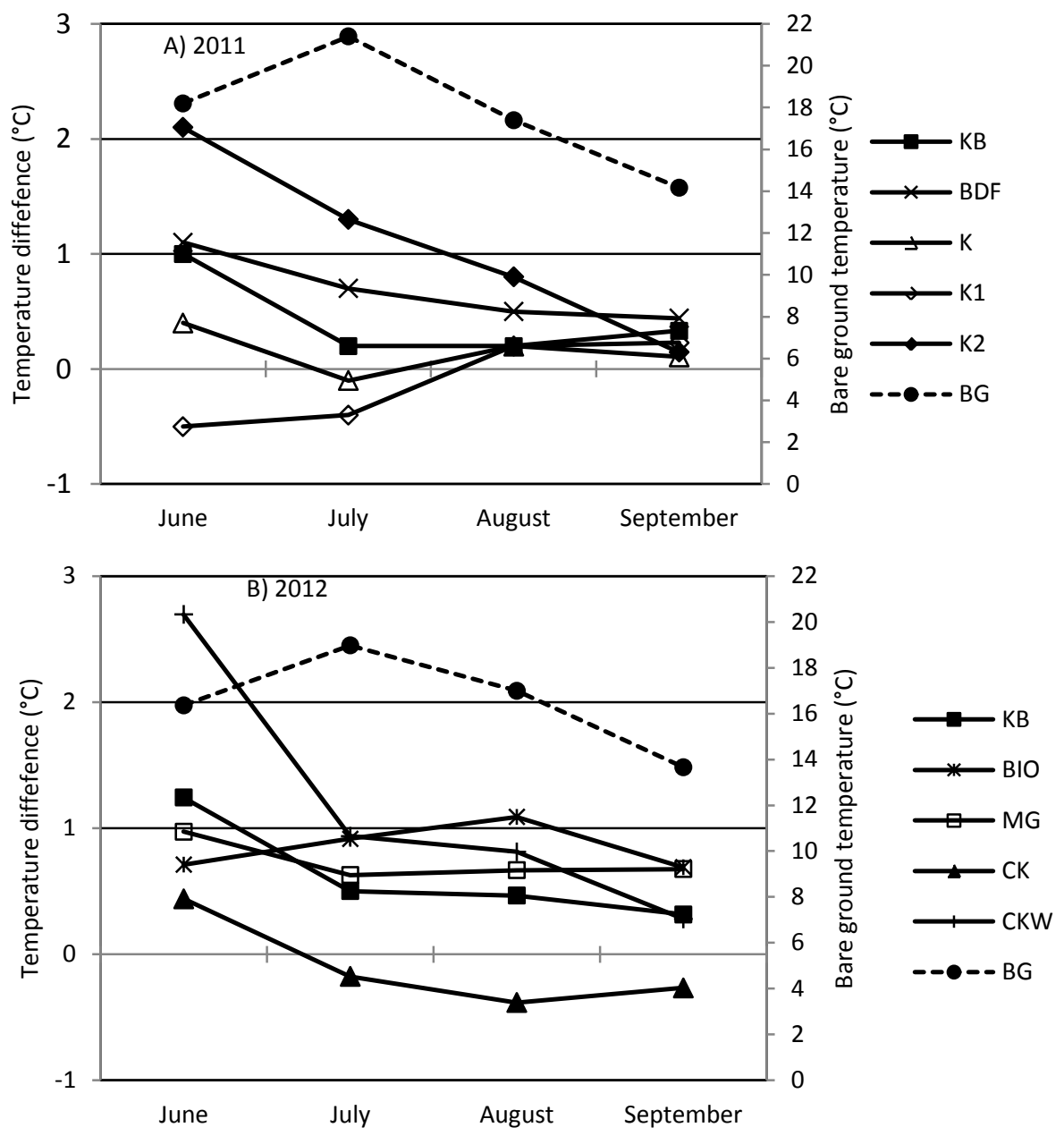

Fig. 1. Mean soil temperature difference under the different mulches as compared to bare ground (left $\mathrm{Y}$-axis) and the mean bare ground temperature (BG) (dotted line, right Y-axis). A) In 2011, KB = brown kraft paper with the upper surface colored black, BDF = biodegradable film, $\mathrm{K}=$ brown kraft paper, $\mathrm{K} 1$ = brown kraft paper coated on the underside with black biodegradable film, K2 = brown kraft paper coated on both sides with black biodegradable film. B) In 2012, KB = brown kraft paper with the upper surface colored black, $\mathrm{BIO}=$ biodegradable film Bioska, MG = MimGreen kraft paper with black upper side, $\mathrm{CK}=$ creped kraft paper and CKW = creped kraft paper with wax coating. 
In 2012, biodegradable film (BIO) and creped kraft paper with wax coating (CKW) increased the average soil temperature as compared to bare ground (Table 3 ). The average soil temperature was lower under creped kraft paper (CK) than under BIO, kraft papers with black upper side (KB and MG), or CKW. In June, CKW increased the soil temperature by $2.7^{\circ} \mathrm{C}$, the temperature under the other mulches being lower (Fig. 1). This transparent mulch transmitted more solar radiation warming the soil under the mulch. In July and September, none of the mulches significantly increased soil temperature. In August, only BIO increased soil temperature.

Table 3. Number of fruits and yield of cucumbers grown on different mulches, and average soil temperatures (T) under the mulches in 2012. $\mathrm{BG}=$ bare ground, $\mathrm{KB}=$ brown kraft paper with the upper surface colored black, $\mathrm{BIO}=$ biodegradable film Bioska, MG = MimGreen kraft paper with black upper side, $\mathrm{CK}=$ creped kraft paper, and CKW = creped kraft paper with wax coating

\begin{tabular}{lccc}
\hline Mulch & $\begin{array}{c}\text { Fruits } \\
\left(\mathrm{no} \mathrm{m}^{-2}\right)\end{array}$ & $\begin{array}{c}\text { Yield } \\
\left(\mathrm{kg} \mathrm{m}^{-2}\right)\end{array}$ & $\begin{array}{c}\text { T June to Sept. } \\
\left({ }^{\circ} \mathrm{C}\right)\end{array}$ \\
\hline BG & $40 \pm 4^{\mathrm{b}}$ & $4.3 \pm 0.4^{\mathrm{b}}$ & $16.9^{\mathrm{y} \mathrm{bc}}$ \\
KB & $74 \pm 6^{\mathrm{ab}}$ & $8.3 \pm 0.6^{\mathrm{a}}$ & $17.5^{\mathrm{ab}}$ \\
$\mathrm{BIO}$ & $81 \pm 6^{\mathrm{a}}$ & $9.1 \pm 0.6^{\mathrm{a}}$ & $17.8^{\mathrm{a}}$ \\
MG & $72 \pm 3^{\mathrm{ab}}$ & $7.9 \pm 0.4^{\mathrm{a}}$ & $17.6^{\mathrm{ab}}$ \\
$\mathrm{CK}$ & $74 \pm 12^{\mathrm{ab}}$ & $8.2 \pm 1.4^{\mathrm{a}}$ & $16.6^{\mathrm{c}}$ \\
$\mathrm{CKW}$ & $72 \pm 12^{\mathrm{ab}}$ & $8.0 \pm 1.4^{\mathrm{a}}$ & $17.9^{\mathrm{a}}$ \\
$p$ & 0.032 & $0.028^{\mathrm{a}}$ & 0.006 \\
\hline
\end{tabular}

Values are means of four replicates and followed by \pm SEM. Values within columns followed by different letters are significantly different $(p<0.05)$ according to SNK test.

${ }^{y} n=3$

${ }^{x} \mathrm{n}=2$

Cucumbers on all the mulches produced higher yields than on bare ground (Table 3). The tested paper mulches (KB, MG, CK, CKW) and biodegradable mulch film did not differ significantly from each other in yield production. In both years, mulching increased the yield due to increased fruit numbers. The average fruit weight was $94.6 \mathrm{~g}$ in 2011 , and $110.5 \mathrm{~g}$ in 2012, and was not affected by mulch treatment.

Mulching can increase the soil temperature and moisture content, and also the yield (El Nemr 2006), and in some studies mulching has improved the growth and earliness of cucumber plants (Salokangas 1973, Pessala and Hårdh 1977). Some studies have indicated that a low root temperature restricts water uptake and top growth of cucumber plants, and may cause wilting and a long-term retardation of stem and leaf growth (Karlsen 1980, Krug and Thiel 1985, Lorenzo et al. 1999). The lower root temperature may also decrease the cucumber yield (Lorenzo et al. 2005), whereas a higher soil temperature has been observed to promote the stem and leaf growth of cucumbers (Krug and Thiel 1985). According to Ibarra-Jiménez et al. (2008), yield increments caused by mulching are partly due to an increase in soil temperature and photosynthesis.

Transparent or black polyethylene or straw as mulching materials increased the yield of pickling cucumber as compared to bare ground in a study by Gebologlu and Saglam (2002). In an earlier study conducted in Finland, an increase in soil temperature caused by polyethylene mulch clearly improved the cucumber yield, more than doubling it in summers with low temperatures (Salokangas 1973). Gosselin and Trudel (1985) demonstrated that an increased soil temperature in Quebec, Canada, may improve the cucumber yield in spring, but has minor effects in the fall. Likewise, in our study, the greatest effect on soil temperature was observed in the spring, leading to increases in early yields (data not shown). In Germany, cucumber yields were increased when the soil temperature increased from 16 to $18{ }^{\circ} \mathrm{C}$ (Krug and Thiel 1985). However, in Poland, no difference in the total or marketable yield of cucumbers or the quality of fruits was observed when grown on black polyethylene mulch or in unmulched soils (Spizewski et al. 2010). Similarly, although Hanna (2000) observed higher soil temperatures under black plastic than under white plastic mulch, the growth of cucumber plants was not affected.

In our study, black printed kraft paper produced higher total and early yields (data not shown) than kraft paper alone in the 2011, when the summer was warmer than the year after. This observation is supported by the study of Hallidri (2001), in which black, silver or transparent polyethylene films or wheat straw were used as mulches in a greenhouse. Black film increased the soil temperature more than other mulching materials, and gave the highest early production of cucumber. 
Weeding was carried out only once in the uncovered control plots in both years. Cucumber growth was vigorous and leaves shaded the soil surface so that further weeding was not necessary. All the mulches controlled the growth of weeds so efficiently that weeding was not needed. Mulches with a black color were not even lifted by the weeds due to their total growth suppression. The light colored paper mulches and especially the waxed one allowed growth of weeds under the mulches (Fig. 2). The weeds did not penetrate the mulches, but grew through the planting holes. However, their number was that low and size small and they were quite equally distributed to all the plots that we do not think that they significantly affected the results. In earlier studies, black-colored paper mulch (Brault et al. 2002) and black paper mulch coated with latex (Zhang et al. 2008a, b) have offered complete weed control in cucumber production. Under beige paper mulches, dicotyledonous weeds were found, but they did not develop beyond the cotyledonary or two-leaf stage (Zhang et al. 2008a, b).

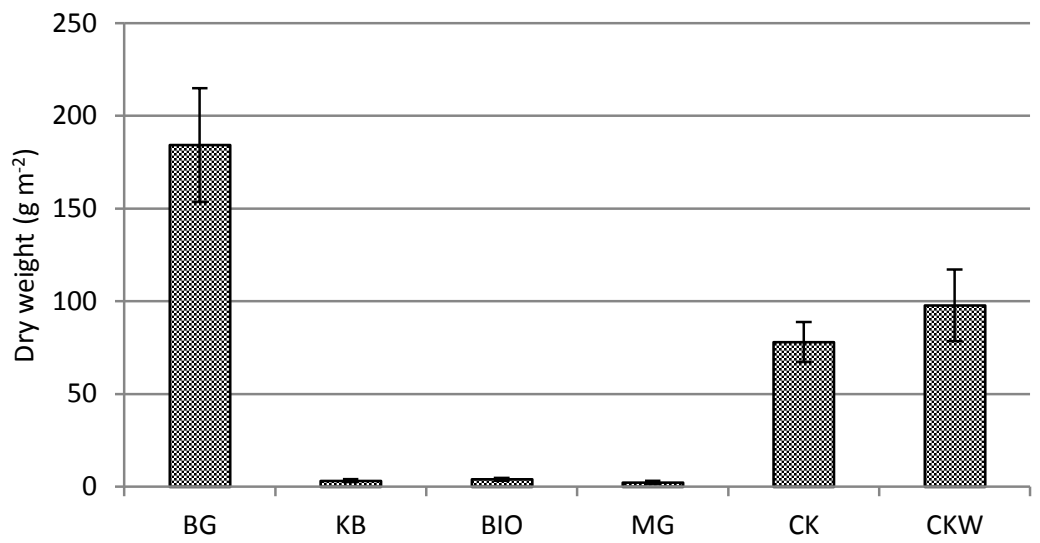

Fig. 2. Dry weight of the weeds harvested 45 days after transplanting (30 July, 2012) from cucumber plots covered with different mulches. $B G=$ bare ground, $K B=$ brown kraft paper with the upper surface colored black, $\mathrm{BIO}=$ biodegradable film Bioska, MG = MimGreen kraft paper with black upper side, $C K=$ creped kraft paper and CKW = creped kraft paper with wax coating. Vertical bars present $\pm \operatorname{SEM}(n=4)$.

Many of the paper mulches, especially the ones not coated with biodegradable film, degraded on their sides, detaching them from the soil, whereas the coated ones remained intact for much longer. Brault et al. (2002) observed that even though the mulches used in cucumber production aged and degraded, they remained in place until harvest. We assume that the vigorous growth of the cucumber plants helped to keep the mulches in place. The paper mulches coated with the biodegradable film were clearly more durable than the film alone. In the case of cucumbers, the most important characteristic of the mulch material is that it increases the soil temperature and is durable enough to last in place and control weeds until the crop plant has sufficiently covered it and shades the ground to control weeds. A clear advantage of biodegradable material is that it can be left on ground and ploughed under, or collected and burnt or composted once the crop is finished. This makes it environmentally much more acceptable than the use of plastic.

In conclusion, mulching with paper or biodegradable plastic, and especially the mulches with a dark upper surface increased the yield of cucumber. These dark-colored mulches also had the greatest soil warming effect and controlled the weeds efficiently. Based on our results, black-printed paper mulch was comparable to biodegradable film in yield production and could replace it in cucumber production

\section{Acknowledgements}

We thank all of the advisory committee members of the Development of paper mulches - research project (AGRIPAP) and the Finnish Funding Agency for Technology and Innovation (TEKES), for financially supporting the work. We also want to thank Dr. Hannu Mikkola and Dr. Antti Korpela for their valuable comments on the article. 


\section{References}

Anderson, D.F., Garisto, M.A., Bourrut, J.-C., Schonbeck, M.W., Jaye, R., Wurzberger, A. \& DeGregorio, R. 1995. Evaluation of a paper mulch made from recycled materials as an alternative to plastic film mulch for vegetables. Journal of Sustainable Agriculture 7: 39-61.

Anzalone, A., Cirujeda, A., Aibar, J., Pardo, G. \& Zaragoza, C. 2010. Effect of biodegradable mulch materials on weed control in processing tomatoes. Weed Technology 24: 369-377.

Brault, D., Stewart, K.A. \& Jenni, S. 2002. Optical properties of paper and polyethylene mulches used for weed control in lettuce. HortScience 37: 87-91.

Cirujeda, A., Aibar, J., Anzalone, Á., Martín-Closas, L., Meco, R., Moreno, M.M., Pardo, A., Pelacho, A.M., Rojo, F., Royo-Esnal, A., Suso, M.L. \& Zaragoza, C. 2012. Biodegradable mulch instead of polyethylene for weed control of processing tomato production. Agronomy for Sustainable Development 32: 889-897.

Coolong, T. 2010. Performance of paper mulches using a mechanical plastic layer and water wheel transplanter for the production of summer squash. HortTechnology 20: 319-324.

El-Nemr, M.A. 2006. Effect of mulch types on soil environmental conditions and their effect on the growth and yield of cucumber plants. Journal of Applied Sciences Research 2: 67-73.

Espi, E., Salmerón, A., Fontecha, A., García, Y. \& Real, A.I. 2006. Plastic films for agricultural applications. Journal of Plastic Film and Sheeting 22: 85-102.

Gebologlu, N. \& Saglam, N. 2002. The effect of different plant spacing and mulching materials on the yield and fruit quality of pickling cucumber. Acta Horticulturae 579: 603-607.

Gosselin, A. \& Trudel, M.-J. 1985. Influence of root-zone temperature on growth, development and yield of cucumber plants cv. Toska. Plant and Soil 85: 327-336.

Halley, P. 2001. Developing biodegradable mulch films from starch-based polymers. Starch-Stärke 53: 362-367.

Hallidri, M. 2001. Comparison of the different mulching materials on the growth, yield and quality of cucumber (Cucumis sativus L.). Acta Horticulturae 559: 49-53.

Hanna, H.Y. 2000. Black polyethylene mulch does not reduce yield of cucumbers double-cropped with tomatoes under heat stress. HortScience 35: 190-191.

Hochmuth, B. \& Hochmuth, G. 1994. Responses of pepper and watermelon to paper and polyethylene mulches in two spring seasons in north Florida. Proceedings of the Florida State Horticultural Society 107: 102-105.

Ibarra-Jiménez, L., Zermeño-González, A., Munguía-López, J., Quezada-Martin, M.A.R. \& de la Rosa-lbarra, M. 2008. Photosynthesis, soil temperature and yield of cucumber as affected by colored plastic mulch. Acta Agriculturae Scandinavica, Section B Soil \& Plant Science 58: 372-378.

Jenni, S., Brault, D. \& Stewart, K.A. 2004. Degradable mulch as an alternative for weed control in lettuce produced on organic soils. Acta Horticulturae 638: 111-118.

Karlsen, P. 1980. The influence of root and air temperature on young cucumber plants. Acta Horticulturae 118: 95-103.

Kirnak, H. \& Demirtas, M.N. 2006. Effects of different irrigation regimes and mulches on yield and macronutrition levels of dripirrigated cucumber under open field conditions. Journal of Plant Nutrition 29: 1675-1690.

Krug, H. \& Thiel, F. 1985. Effect of soil temperature on growth of cucumber in different air temperature and radiation regime. Acta Horticulturae 156:117-126.

Lorenzo, P., Sanchez-Guerrero, M.C. \& Castilla, N. 1999. Soilless cucumber response to mulching in an unheated Mediterranean greenhouse. Acta Horticulturae 491: 401-404.

Lorenzo, P., Sanchez-Guerrero, M.C., Medrano, E., Soriano, T. \& Castilla, N. 2005. Responses of cucumbers to mulching in an unheated plastic greenhouse. The Journal of Horticultural Science \& Biotechology 80: 11-17.

Minuto, G., Pisi, L., Tinivella, F., Bruzzone, C., Guerrini, S., Versari, M., Pini, S. \& Capurro, M. 2008. Weed control with biodegradable mulch in vegetable crops. Acta Horticulturae 801: 291-297.

Moreno, M.M. \& Moreno, A. 2008. Effect of different biodegradable and polyethylene mulches on soil properties and production in a tomato crop. Scientia Horticulturae 116: 256-263.

Necibi, S., Barrett, B.A. \& Johnson, J.W. 1992. Effects of a black plastic mulch on the soil and plant dispersal of cucumber beetles, Acalymma-vittatum (F) and Diabrotica-undecimpunctata-howardi Barber (Coleoptera: Chrysomelidae), on Melons. Journal of Agricultural Entomology 9: 129-135.

Nimah, M.N. 2007. Cucumber yield under regular deficit irrigation and mulching treatments. Acta Horticulturae 731: 189-194.

Pessala, R. \& Hårdh, K. 1977. Mulching in the cultivation of pickling cucumber. Annales Agriculturae Fenniae 16: 64-71.

Salokangas, K. 1973. Effect of polyethylene and paper mulching on yield and earliness of pickling cucumber. Acta Horticulturae 27: $223-226$

Sarnacke, P. \& Wildes, S. 2008. Disposable bioplastics. Consumer disposables agricultural films, a market opportunity study, April 2008. Available in the internet at: http://soynewuses.org/wp-content/uploads/pdf/DisposalblePlasticsMOS.PDF. 35 p.

Spizewski, T., Frąszczak, B., Kałużewicz, A., Krzesiński, W. \& Lisiecka, J. 2010. The effect of black polyethylene mulch on yield of field-grown cucumber. Acta Scientiarum Polonorum, Hortorum Cultus 9: 221-229.

Zhang, Y., Han, J.H. \& Kim, G.N. 2008a. Biodegradable mulch film made of starch-coated paper and its effectiveness on temperature and moisture content of soil. Communications in Soil Science \& Plant Analysis 39: 1026-1040.

Zhang, S., Raza, W., Yang, X., Hu, J., Huang, Q., Xu, Y., Liu, X., Ran, W. \& Shen, Q. 2008b. Control of Fusarium wilt disease of cucumber plants with the application of a bioorganic fertilizer. Biology and Fertility of Soils 44: 1073-1080. 